\title{
ACRL candidates for 1996 elections
}

\author{
Be sure to vote in the election \\ this spring
}

$\mathbf{T}$ he listing for each of the candidates includes their title and institution.

\section{Vice-President/President-Elect}

W. Lee Hisle, Dean of Learning Resources Services, Austin Community College; Bernard Fradkin, Dean of Learning Resources Center, College of DuPage.

\section{Afro-American Studies Librarians Section}

Vice-Chair/Chair-Elect: Itibari $M$. Zulu, Librarian, UCLA Center for African-American Studies; Sylvia Y. Curtis, Black Studies and Dance Librarian, Universiry of California, Santa Barbara. Secretary: Alice Reviere Smith, English/Black Studies/Women's Studies Librarian, Cleveland State University; Carol Ritzen Kem, Department of Collection Development, University of Florida. Member-at-Large (1 year): Mary G. Wrighten, Multicultural Services Reference Librarian, Bowling Green State University; Heather Martin, Reference and Outreach Librarian, Wright State University.

Member-at-Large (2 years): Stanton Biddle, Administrative Services Librarian, Baruch College, City University of New York; Mark G. R. McManus, Associate Director, West Georgia College Library.

\section{Anthropology and Sociology Section}

Vice-Chair/Chair-Elect: Joyce L. Ogburn, Chief Acquisitions Librarian, Yale University; write in. Member-at-Large: Gary A. McMillan, Head, Social Work Library, Howard University; Gregory A. Finnegan, Associate Librarian for Public Service/Head of Reference, Tozzer Library, Harvard University.

\section{Arts Section}

Vice-Chair/Chair-Elect: HenryJ. DuBois, Act- ing Associate Director, University Library, California State University-Long Beach; Stephen Bloom, Director of University Libraries, University of the Arts.

\section{Asian, African, and Middle Eastern Section}

Vice-Chair/Chair-Elect: Robert Ridinger, Chair, Humanities and Behavioral Science Section, Northern Illinois University Libraries.

Member-at-Large (elect two): Talbott Huey, Bibliographer and Coordinator, Michigan State University; Peter Malancbuk, Africana and Political Science Bibliographer, University of Florida; Margaret Wang, Coordinator of Original Cataloging, University of Delaware; Ann Wood, Reference Librarian, University of Massachusetts, Amherst.

\section{Community and Junior College Libraries Section}

Vice-Chair/Chair-Elect: Wanda K. Johnston, Director of Learning Resources, Central Florida Community College; Mary Dolven, Director of Library Services, Contra Costa Community College District.

Secretary: Steven W. Hagstrom, Director of Library Services, Tarrant County Junior College; Kate Hickey, Director of the College Library, Pennsylvania College of Teaching.

\section{College Libraries Section}

Vice-Chair/Chair-Elect: Damon Hickey, Director of Libraries, The College of Wooster; Larry Oberg, University Librarian, Willamette University.

Secretary: Marilyn Mitchell, Library Director, University of Puget Sound; Mickey Zemon, I)irector of Libraries, Emerson College.

Member-at-Iarge: Peter Deekle, College Librarian, Wheaton College; Tara Fulton, Assistant Director, Bertrand Library, Bucknell University.

\section{Education and Behavioral Sciences Section}

Vice-Chair/Chair-Elect: Dorotby $M$. Persson, 
Head Librarian, Psychology Library/Physics Library, University of Iowa; Nancy Weissinger, Electronic Resources Librarian, Teachers College, Columbia University.

Member-at-Large: Allison Kaplan, Cataloger, University of Delaware; Jane McKeever, Billiographer for Education. Psychology and Library Science, University of Chicago.

\section{English and American Literature Section}

Vice-Chair/Chair-Elect: Susanna Pathak. Resource Services Librarian, Johns Hopkins University; Betty' H. Day', Humanities Bibliographer, University of Maryland.

Secretary: Catherine Palmer, Humanities Librarian, University of California, Irvine; Yonne Schofer, Humanities-English Bibliographer, University of Wisconsin, Madison.

Member-at-Large: Danielle J. Uchitelle, Director, Center for Information Services, Modern Language Association: Loretta Koch, Humanities Librarian, Southern Illinois University Libraries.

\section{Extended Campus Libraries Services Section}

Vice-Chair/Chair-Elect: Marie Kascus, Librarian/Head of Serials, Central Connecticut State University; Nancy Burich, Regents Center Librarian, University of Kansas.

Secretary: S. David Mash. Director of Academic Information Services, Columbia International University; Bettina Meyer, Assistant Dean for Resources, Western Michigan University.

Member-at-Large: Monica Craig, Off-Campus Librarian. Central Michigan University; Janet Feldmann, Head Librarian, Indiana UniversityPurdue University Indianapolis.

\section{Instruction Section}

Vice-Chair/Chair-Elect: Randy Burke Hensley: Chair. Reference Center, University of Hawaii at Manoa; Karen Williams, Social Sciences Team Leader, University of Arizona.

Secretary: Suzanne Byron, Head of User Education. University of Northern Texas; Scott Mandemack, Reference and Instruction Librarian, Purdue University.

Member-at-Large: Rebecca Jackson, Coordinator of User Education Programs, George Washington University; Beth Sandore, Coordinator for Imaging Projects and Associate Professor of Library Administration, University of Illinois at Urbana-Champaign.

\section{Law and Political Science Section}

Vice-Chair/Chair-Elect: Stephen Stilluell, Ph.I). Candidate, University of North Texas; Panla J. Popma, Assistant University Librarian for Access Services, Santa Clara University.

Member-at-Large: Marifran Bustion, Head, Acquisitions Department, George Washington University.

\section{Rare Books and Manuscripts Section} Vice-Chair/Chair-Elect: Maruin J. Taylor: Head of Special Collections, New York University; Laura Stalker, Associate Director for Technical Services, The Huntington Library.

Member-at-Large: Suzy Taraba, Public Services Librarian, University of Chicago; William E. Brown fr., Head, Archives and Special Collections, University of Miami.

\section{Slavic and Eastern European Section}

Vice-Chair/Chair-Elect: Bradley L, Schaffner, Slavic Studies Librarian, University of Kansas.

Secretary: Richard Fitzsimmons, Director of the Library, Pennsylvania State UniversityScranton Campus.

Member-at-Large: Julie Suann, Catalog Librarian/Slavic Languages and Literature Liaison Librarian, University of Nebraska.

\section{Science and Technology Section}

Vice-Chair/Chair-Elect: Allison V. Level, Science Reference Librarian, Library of Congress; Ann Paietta, Networked Programs Coordinator, New York Academy of Medicine.

Secretary: Nirmala Bangalore, Assistant Cata$\log$ Librarian, University of Illinois at Chicago; Terry Wittig, Collections Coordinator/Science Information Specialist, Carnegie Mellon-Engineering and Science Library; Katherine Whitley, Reference Librarian, Chemistry Information Specialist, University of California, San Diego.

\section{University Libraries Section}

Vice-Chair/Chair-Elect: Sharon Bonk, Chief Librarian, Queens College; Lori A. Goetsch, Head, Reference Services, University of Tennessee at Knoxville.

Member-at-Large (elect two): Joan Giesecke, Associate Dean for Collections and Services, University of Nebraska-Lincoln: Helen $H$. Spalding, Associate Director of Libraries, University of Missouri-Kansas City; Jordan Scepanski, Director of the Library and Learning Resources, California State University-Long (Candidates cont. on page 769) 
has many interdependent facets. The level of support necessary will depend on the scope and size of the program.

The following kinds of support should be present:

\section{a. Instructional Facilities}

a. 1. The library should have or should have ready access to facilities of sufficient size and number that are equipped to meet the goals of the instruction program and reach the entire learning community, including distant learners, remote users, or individuals in extended campus communities.

a. 2. The instruction setting(s) should duplicate the equipment and technology available to users. The minimum acceptable level is that the instructor can demonstrate information systems available to the library's users. The desirable level is that those being instructed can have hands-on experience with these systems.

a. 3. The instruction setting should be flexible enough to accommodate a variety of teaching methods and learning styles.

\section{b. Work Facilities for Librarians and Staff}

b. 1. The library should provide convenient access to the equipment and services necessary to design, produce, reproduce, and upclate instruction materials in a variety of technological formats.

b. 2. The library should provide sufficient space for the preparation and storage of instruction materials.

\section{c. Financial Support}

c. 1 . The funding for an instruction program should include all personnel costs connected to the program.

c. 2. The instruction program should have iclentified funds that are realistic and adequate to attain the stated goals of the program.

c. 3. The funding should cover: supplies and materials; student, clerical, and technical assistance; equipment or access to equipment; design, production, and reproduction of materials; revision and updating of materials; and promotion and marketing of the instruction program.

c. 4. The allocation process should recognize that equipment and software replacement and enhancement will be necessary as technologies used for instruction or for information retrieval change. c. 5. The funding should recognize the need for the training and continuing eclucation of those involved in the instruction program.

\section{d. Support for Staff Continuing Education, Training, and Development}

Nonmonetary support for continuing staff development helps to establish an atmosphere conducive to innovation and high morale. It is recommended that instruction coordinators:

d. 1. provicle every staff member with a written description of the scope of his/her responsibilities;

d. 2. provicle a structured program for orientation and training of new instruction personnel;

d. 3. develop a program of continuing education to develop advanced instruction skills;

d. 4 . conduct periodic review of staff performance in instructional activities.

(Candidates cont. from page 766)

Beach; Joan G. Rapp. Director of Libraries, University of Missouri-St. Louis.

\section{Western European Specialists Section}

Vice-Chair/Chair-Elect: Heleni Pedersoli, Bibliographer for Foreign Languages, University of Maryland: Kurt DeBelder, Assistant Curator, Western European Literature and Languages, New York University.

Secretary: Roger Brisson, Social Sciences Cataloger, Pennsylvania State University; Martba Hsu, North European Studies Bibliographer, Cornell University.

Member-at-Large: Sarab How, Western European Social Science Bibliographer, Cornell University; Nancy S. Boemer, Subject Specialist for Modern European Languages, Classical Studies, Linguistics, and West European Studies, Indiana University.

\section{Women's Studies Section}

Vice-Chair/Chair-Elect: Jessica Grim, Acting Head of Reference, Oberlin College; Write-In. Secretary: Shelley Arlen, Reference Librarian/ Bibliographer, University of Florida; Barbara Heath, Assistant Director for Technical Services and Team Leader-Acquisitions and Original Cataloging Teams, Wayne State University

Member-at-Large: Theresa Tobin, Humanities and Dewey Librarian, MIT; Mila C. Siu, Senior Assistant Librarian, Pennsylvania State University, Altoona Campus. 